\title{
Bulbosas ornamentais no Brasil ${ }^{(1)}$
}

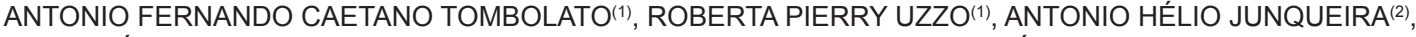 \\ MÁRCIA DA SILVA PEETZ(2), GIULIO CESARE STANCATO(1) e MARIA AMÉLIA VAZ ALEXANDRE ${ }^{(3)}$
}

\begin{abstract}
RESUMO
O mercado de bulbosas no Brasil, no ano de 2010, movimentou um valor total de exportação da ordem de US\$13-14 milhões e de importação de US\$ 7,3 milhões. Este trabalho apresenta os resultados de um levantamento feito nos mercados de flores do estado de São Paulo, somados a dados e informações obtidas junto aos principais produtores de bulbosas ornamentais. As principais espécies cultivadas e comercializadas no País como flores de corte e vaso são: alstroeméria (Alstroemeria sp.); amarílis (Hyppeastrum sp.); copo-de-leite (Zantedeschia sp.); gladíolo (Gladiolus X grandiflorus); hemerocale (Hemerocallis sp.) e lírio (Lilium sp.). Observou-se que a produção e, consequentemente, o mercado é crescente, porém o País enfrenta um grande entrave interno com relação à legislação que regulamenta a proteção de cultivares e o uso de defensivos químicos.

Palavras-chave: mercado, produção, alstroeméria (Alstroemeria sp.), amarílis (Hyppeastrum sp.), copo-de-leite (Zantedeschia sp.), gladíolo (Gladiolus X grandiflorus), hemerocale (Hemerocallis sp.)
\end{abstract}

\section{ABSTRACT \\ Ornamental bulbs in Brazil}

The ornamental bulbs market in Brazil, in 2010, moved a total value of exports of U.S. \$ 13- 14 million and imported U.S. \$ 7.3 million. This paper presents the results of a survey from the flower markets of São Paulo, in addition to data and information obtained from the major producers of ornamental bulbs. The main species cultivated in Brazil and marketed as cut flowers and pot are: Alstroemeria sp., Hyppeastrum sp., Zantedeschia sp., Gladiolus X grandiflorus, Hemerocallis sp. and Lilium sp. It was noted that production and, consequently, the market is growing, but the country faces a major obstacle with respect to the internal laws governing the protection of plant cultivars and the use of chemical pesticides.

Keywords: market, production, Alstroemeria, Hyppeastrum, Zantedeschia, Gladiolus X grandiflorus, Hemerocallis, Lilium.

\section{INTRODUÇÃO}

O mercado de flores e plantas ornamentais no Brasil movimentou, no ano de 2010, valor global de US\$2,2 bilhões, o que representou crescimento de $15 \%$ sobre os resultados do ano anterior. Ao longo dos últimos anos, o setor florícola brasileiro vem experimentando sucessivas taxas de crescimento da ordem de $8-10 \%$ ao ano nas quantidades e de $12-15 \%$ nos valores comercializados. Tais índices, bastante acima dos níveis médios de crescimento do PIB nacional, comprovam o alto vigor de crescimento sustentado da atividade no país.

No Brasil, as bulbosas ornamentais são cultivadas e comercializadas tanto para consumo de corte, quanto para vasos, paisagismo e jardinagem. Espécies do grupo como alstroeméria (Alstroemeria sp.), amarílis (Hyppeastrum sp.), copo-deleite (Zantedeschia $\mathrm{sp}$.), gladíolo (Gladiolus X grandiflorus), hemerocale (Hemerocallis sp.) e lírio (Lilium sp.) estão entre as principais flores de corte e vaso cultivadas e comercializadas no País.

Em relação ao processo produtivo, o cultivo de ornamentais no País enfrenta um grande entrave interno com relação à legislação que regulamenta o uso de defensivos químicos. Fungicidas, inseticidas, acaricidas e, sobretudo, antibióticos só devem ser utilizados se possuírem registro de uso para a cultura e aplicados de acordo com as normas de segurança. No entanto, produtos específicos registrados para aplicação em ornamentais são ainda muito escassos, e produtos mais eficientes e de alta toxicidade, como o brometo de metila, são proibidos. Outra preocupação dos produtores de bulbosas é a ocorrência comum de tiririca (Cyperus rotundus) nas áreas de cultivo, cujo controle é bastante difícil e oneroso.
Ao longo das últimas décadas, o Brasil tem se destacado no mercado internacional de bulbos. Nesta posição, importa materiais genéticos inovadores de primeira linha originários especialmente da Holanda. Com o recente aquecimento do seu mercado interno, as importações brasileiras de bulbos saltaram de US\$ 4,7 milhões em 2008 para US\$ 8,3 milhões em 2009 , retrocedendo ligeiramente o montante em 2010 (US\$ 7,3 milhões).

Por outro lado, o País também se posiciona como exportador, vendendo para o mercado internacional principalmente bulbos de gladíolos, amarílis e caladium. Observa-se, neste caso, a exploração das vantagens comparativas do Brasil em termos de precocidade de cultivo devido a suas condições ecológicas privilegiadas, além de custos competitivos, o que o torna apto ao regime de importar para reproduzir e exportar novos bulbos para Holanda, EUA e outros países. Observa-se que, ao longo do período de 1999 a 2005, as exportações brasileiras de bulbos de plantas ornamentais se situaram no intervalo de US\$ 4-6 milhões anuais. A partir de então, as vendas ao mercado internacional dessas mercadorias saltaram para o patamar de US\$ 13-14 milhões anuais.

\section{PRINCIPAIS BULBOSAS NOS MERCADOS INTERNO E EXTERNO}

\section{LÍRIO}

O lírio possui grande popularidade no mercado de flores, tanto envasadas como de corte. É considerada a quinta flor mais vendida do mundo e no Brasil está em terceiro lugar.

Estima-se que sejam plantados anualmente para a produção de flores de lírios entre 20 e 22 milhões de bulbos. Deste

\footnotetext{
(1) Pesquisador Científico, Instituto Agronômico (IAC), Av. Barão de Itapura, n.1481, CEP 13020-902, Campinas/SP, e-mail: tombolat@iac.sp.gov.br

(2) Hórtica Consultoria e Treinamento, www.hortica.com.br, São Paulo/SP, e-mail: helio@hortica.com.br

(3) Pesquisadora Científica, Instituto Biológico (IB), Av. Conselheiro Rodrigues Alves, 1252, CEP 04014-002, São Paulo/SP, e-mail: alexand@biologico.sp.gov.br
} 
total, uma parcela de $60 \%$ destina-se ao mercado de corte e os $40 \%$ restante se voltam para a produção de flores envasadas. O tipo oriental representa $70 \%$ e o asiático $30 \%$ do total comercializado anualmente.

As principais regiões produtoras de lírio de corte estão concentradas nos platôs e nas montanhas dos estados de São Paulo, Minas Gerais, Rio de Janeiro e Rio Grande do Sul. A oferta apresenta picos nos meses de setembro a dezembro. Já para os lírios envasados, a produção está mais concentrada no Estado de São Paulo, especialmente nos municípios de Holambra, Jarinu, Campinas, Registro, Monte Mor, Jacareí, Atibaia e Cotia.

O mercado brasileiro para lírios em vasos é crescente, movimentando pouco mais de 4 milhões de unidades por ano nos principais mercados atacadistas. A oferta é consideravelmente expandida no mês de maio, com foco na comercialização para o Dia das Mães, e em dezembro, para as ornamentações natalinas e de Revéillon.

No Brasil, atualmente, a produção comercial se concentra na região Sudeste, sendo que em 2004 existiam 6 produtores em Holambra. O processo produtivo de lírio de vaso é iniciado a partir de bulbos importados de várias empresas da Holanda, e cada produtor faz sua própria importação. Esse material é tratado fitossanitariamente e transportado em navios em containeres climatizados a uma temperatura de $-1^{\circ} \mathrm{C}$ a $-1,5^{\circ} \mathrm{C}$.

\section{Principais parâmetros da produção à comercialização}

Um dos maiores produtores cultiva as flores de corte em campo aberto, em região de $1.300 \mathrm{~m}$ de altitude. Outros produtores, em região de $600 \mathrm{~m}$ de altitude, produzem em caixas coletivas colocadas em telados com baixo sombreamento com o uso de tela preta ou refletora a $40 \%$ sobre tijolos e não diretamente no chão. Esta prática favorece a manutenção de temperatura mais baixa pela ventilação e o controle de pragas e doenças do solo. Este sistema favorece o manuseio da produção, pois, logo após o plantio, é necessário o acondicionamento em câmara fria $\left(12-17^{\circ} \mathrm{C}\right)$ para indução do enraizamento.

Com relação ao aspecto fitossanitário, as principais doenças que afetam a cultura no verão são causadas por Phytophthora e Pythium e sua principal praga, o pulgão. O aparecimento de manchas cloróticas e de deformação foliar é causado pelo vírus Cucumber mosaic virus (CMV), atingindo cultivos em várias regiões do país. Do gênero Potyvirus, foram encontradas as espécies Bean yellow mosaic virus (BYMV), que causa o sintoma de mosaico clorótico em faixas e o Tulip breaking virus (TBV), que induz o aparecimento de mosqueado, riscas e lesões necróticas em folhas e quebra de coloração nas pétalas. Recentemente foi descrito no Brasil o Lily symptomless virus (LSV) - Carlavirus, que pode ser detectado em plantas assintomáticas ou com sintomas de mosaico, clareamento de nervuras, amarelecimento das folhas, redução no porte, deformação de flores e diminuição de bulbos.

O ciclo da cultura, para os lírios asiáticos, varia de 90 dias no verão a até 105 dias, no inverno. Já para os lírios orientais, o ciclo é mais longo, 120 dias no verão a até 135 dias no inverno.

A produção para flores de vaso é feita em vasos de 13 a 17 $\mathrm{cm}$ de diâmetro, contendo três bulbos cada. A irrigação é feita por aspersão ou gotejamento.

No mercado brasileiro, são cultivados, tanto para corte, quanto para vasos, lírios nas cores branca, amarela, vermelha, laranja e rosa em diversas tonalidades e intensidades. No caso dos lírios orientais, as principais cultivares plantadas são aquelas que produzem flores brancas. Já para o lírio asiático, a preferência recai sobre as flores de cor laranja, seguida das cores amarela e branca. Neste caso, as tendências observadas junto ao mercado consumidor apontam para a preferência cada vez mais pronunciada por cores fortes, como a cor laranja e, também, a amarelo-ouro.

A seguir estão relacionadas as principais variedades inseridas em cada um dos grupos de lírios, conforme sua cor e origem:

\section{- Oriental:}

Branco - 'Siberia', 'Muscadet', 'Expression', 'Pompei', 'Free Choice', 'Luzia', 'Cold Play';

Rosa - 'Sorbonne', 'Farolito', 'Star Gazer', 'Mona Lisa', 'Acapulco', 'Entertainer', 'Showwiner';

Vinho - 'Mero Star', 'Love Story';

Bicolor - 'Acoustic', 'Casa Blanca', 'Starling Express', 'Rodolfa', 'True Emotion', 'Roussillon', 'Salmon Star', 'Space' and 'Star'.

\section{- Asiático:}

Branco - 'Navona', 'Tiny Snowflake', 'Tiny Nanny';

Laranja - 'Brunello', 'Orange Pixie', 'Tiny Dino', 'Skyline Tiny';

Amarelo - 'Cordelia', 'Gironde', 'Golden Joy', 'Tiny Bee'; Gold: 'Golf';

Vermelho - 'Monte Negro';

Wine - 'Tiny Ghost', 'Tridex';

Rosa: 'Vivaldi', 'Tiny Icon'; Bicolor - 'Tiny Sensation', 'Tiny Todd', 'Elite', 'Romano'.

\section{- Japonês (Longiflorum):}

Branco - 'Snow Queen', 'White Elegance', 'White Europe', 'White Heaven'.

\section{- Longiflorum x Asiático: \\ Amarelo - 'Aladdin's Dazzle'; \\ Creme - 'Royal Fantasy'; \\ Salmão - 'Donau', 'Salmon Classic'.}

\section{Critérios de classificação para lírio de corte}

Há critérios distintos de classificação de lírios de corte e de vaso adotados na comercialização dessas flores.

De acordo com os critérios de classificação comercial de lírios de corte da Cooperativa Veiling Holambra, são considerados 6 diferentes grupos: a) oriental, b) asiático, c) longiflorum, d) longiflorum $\mathrm{x}$ asiático, e) longiflorum $\mathrm{x}$ oriental e f) oriental $x$ trombetelilie.

As classes do produto são definidas conforme o comprimento das hastes: a) Classe 40 (hastes de $40 \mathrm{~cm}$ de comprimento); b) Classe 50 (hastes de $50 \mathrm{~cm}$ de comprimento); c) Classe 60 (hastes de $60 \mathrm{~cm}$ de comprimento); d) Classe 70 (hastes de $70 \mathrm{~cm}$ de comprimento); e) Classe 80 (hastes de $80 \mathrm{~cm}$ de comprimento); e f) Classe 90 (hastes de $90 \mathrm{~cm}$ de comprimento).

Outro critério de classificação adotado é relacionado ao número de botões viáveis por haste, que pode variar de 1 a 6 . Por esse critério, não são contabilizados os botões imaturos (verdes), que produzirão uma flor aberta.

No caso de apenas 1 botão viável por haste, a comercialização deve se dar em maços de 10 hastes e o botão floral deve estar alinhado na mesma direção da haste central da planta. Para as demais ocorrências, os maços deverão ser de 5 hastes. 
O ponto mínimo de comercialização é de 1 botão por haste, e ele deve permitir o reconhecimento da cor da flor. A única exceção permitida, neste caso, é para as variedades de lírios de coloração amarela. Por outro lado, a presença de flores já abertas é considerada defeito por excesso de maturação e, dependendo da participação relativa dessa ocorrência no lote, o produto vai sendo progressivamente classificado em categorias menos valiosas - de A1 $(10 \%$ de presença de flores abertas) até B (máximo de 30\%). Quando o lote tiver mais de $30 \%$ de presença de flores abertas, o produto deixa de ser comercializado.

Ao enviar seu produto para comercialização, o produtor deve obrigatoriamente informar o ponto de maturação das plantas, com base no grau de abertura dos botões florais, que pode variar em 4 diferentes estádios (de fechado a maduro).

Quanto à qualidade, os lírios de corte são classificados nas categorias A1, A2 ou B, dependendo da ocorrência de defeitos encontrados. Os defeitos graves considerados são: danos por doenças nas flores ou hastes, especialmente aqueles ocasionados por Botrytis; danos ocasionados por pragas (lesma, pulgão, lagarta); danos mecânicos; folhas amarelas; e botões com formação defeituosa. Já os defeitos leves considerados são: queimaduras nas folhas, presença de resíduos químicos, hastes amolecidas e limpeza insuficiente das bases, ou seja, manutenção das folhas desde a base da haste, o que propicia contato com a água de hidratação dos cochos, podendo resultar em contaminação microbiológica. A Cooperativa Veiling Holambra recomenda que as hastes tenham pelo menos $15 \mathrm{~cm}$ totalmente limpos da presença de folhas. No inverno, devido às condições naturais de queda das folhas, pode-se permitir até $50 \%$ do comprimento total da haste limpa, desde que ela esteja em boas condições de sanidade.

Todas as mercadorias enviadas para comercialização devem ser pré-resfriadas na própria área de produção.

As principais datas para comercialização são: Dia das Mães, Dia dos Namorados, Dia da Secretária, Dia Internacional da Mulher, Natal e Réveillon.

Após a classificação, são preparados pacotes com dez hastes, embaladas em plástico que serve para proteção e armazenamento a baixa temperatura. Na comercialização, os pacotes são separados por comprimento de haste e acondicionados em caixas de papelão com até 50 hastes por caixa (Figura 3).

\section{Critérios de classificação para lírio de vaso}

De acordo com os critérios de classificação para lírios de vaso da Cooperativa Veiling Holambra, são considerados os seis grupos já apresentados para as flores de corte, incluindo ainda o grupo Rascal, que se diferencia dos demais por apresentar plantas de menor porte, flores pequenas, folhas ovaladas e hastes firmes. As principais variedades cultivadas deste grupo são: 'Angelique', 'Little Rainbow', 'Souvenir', 'Diamonds', ‘Álibi’ e 'Sombrero'. Já no grupo oriental $\mathrm{x}$ trombeteline, as principais variedades cultivadas são: 'Early Yellow' e 'Tarragona'.

Não são definidos padrões mínimos de altura para o lote de lírios envasados. Recomenda-se, contudo, que na composição do lote, o produtor não permita variações maiores do que 10 $\mathrm{cm}$ entre as menores e as maiores plantas.

As hastes devem estar firmes e autosustentadas nos vasos. Caso isso não seja possível, devem ser tutoradas com estacas individuais.

Os lírios envasados são cultivados em potes 10, 12, 13, 14, 15,16 ou 19. Para as primeiras quatro dimensões, exige-se o número mínimo de 1 haste para a comercialização. Já para os potes 15, 16 e 19, são exigidas 3 hastes. Quanto ao número de botões por vaso, para os lírios orientais são obrigatórios: 2 botões, nos potes 13 e 14; 4 botões nos potes 15; e 16 e 6 , no pote 19. Já para os lírios asiáticos, a regra é: 3 botões nos potes 13 e 14; 8 nos potes 15 e 16; e 10 botões no pote 19 .

Como padrão mínimo de comercialização, observa-se que para os lírios orientais, pelo menos 1 botão do vaso deve permitir o reconhecimento da cor da flor. Já para os lírios asiáticos, é exigido um mínimo de 3 botões nesta condição.

O produtor deve obrigatoriamente informar o grau de maturação das plantas enviadas para comercialização, cuja classificação, segundo o grau de abertura dos botões florais, comporta 4 graus diferentes: fechado, médio, maduro e início de abertura.

Quanto à qualidade, os lírios envasados são classificados nas categorias A1, A2 e B. São considerados quesitos relativos a defeitos graves e leves. Entre os primeiros se encontram: danos causados por doenças nas flores e hastes, especialmente por Botrytis; e danos ocasionados por pragas (lesmas e lagartas), danos mecânicos, folhas amareladas, queimaduras e falta de hidratação. Já os defeitos leves considerados são: presença de resíduos de produtos químicos, limpeza da base fora dos padrões exigidos $(20 \mathrm{~cm}$ para os orientais e $10 \mathrm{~cm}$ para os asiáticos), transplante recente e clorose.

A boa formação da planta exige que as hastes sejam distribuídas sempre de modo a comporem um triângulo no interior do vaso.

\section{GLADÍOLO}

A introdução do cultivo de gladíolos no Brasil se confunde com a saga dos imigrantes holandeses e com a própria história de Holambra, pequena cidade no interior do Estado de São Paulo, considerada o centro da floricultura empresarial nacional.

O casal Klaas e Gemma Schoenmaker deixou a Holanda no final da década de 1950 para imigrar para o Brasil juntamente com seus onze filhos. Aqui, dedicaram-se originalmente ao cultivo do milho, algodão e café, entre outras atividades agropecuárias. Posteriormente, passaram a dedicar-se, também, ao cultivo dos gladíolos (popularmente mais conhecidos como palma-de-santa-rita), aproveitando a experiência que possuíam no cultivo de flores no seu país de origem.

Os bulbos holandeses de gladíolos trazidos por Klaas Schoenmaker no navio logo conquistaram os clientes e consumidores brasileiros, especialmente por serem mais longos e possuírem cores mais variadas do que as encontradas no Brasil. A consequente expansão dos negócios permitiu a formação e a consolidação do Grupo Terra Viva, atualmente a principal empresa produtora de gladíolos no Brasil.

Concomitantemente, a colônia japonesa já estabelecida em regiões próximas à cidade de São Paulo também ingressou na produção de gladíolo. Existem relatos da década de 1950 de que se vendiam mil dúzias de gladíolos em 30 minutos. Nesse período, as flores estavam cotadas a preços altos e se tornavam objeto de desejo das camadas de mais alta renda da sociedade.

O gladíolo como flor de corte foi sendo, aos poucos, substituído por outras espécies de bulbosas ornamentais, principalmente com a introdução de novas variedades de lírio, copode-leite e também de gérbera.

Atualmente, a maior concentração de cultivo está locali- 
zada nas propriedades dos associados da Cooperativa Veiling Holambra, sendo a empresa Terra Viva Bulbos a única produtora de cormos no Brasil. A multiplicação é feita em campo durante todo o ano. A técnica de micropropagação não tem sido empregada. Nessa empresa, $60 \%$ da produção é para o mercado interno, em um total comercializado de 18 milhões de cormos. Outros 40\% (12 milhões) da produção seguem para exportação para a Holanda, a maioria da cor branca. Da Holanda, são redistribuídos para Portugal, Espanha e Itália. Os cormos possuem aproximadamente $34 \mathrm{~g}$ de peso e tamanho de $2,5 \mathrm{~cm}$ de altura e de 3,2 a $3,8 \mathrm{~cm}$ de diâmetro. A limpeza dos cormos é manual, enquanto que a classificação por diâmetro é feita mecanicamente.

\section{Principais parâmetros da produção à comercialização}

No Brasil, o ciclo da cultura é de 65 dias, para as variedades mais precoces.

As principais pragas que ocorrem no país são os tripes ( $\mathrm{Ta}$ eniothrips simplex) que atacam brotos, folhas, botões, flores e cormo, causando aborto da floração, flores deformadas e enfraquecimento das plantas, enquanto o Thripes tabaci (Thripidae) que ataca as folhas e demais partes verdes é um importante vetor de viroses. A lagarta (Heliothis zea), praga comum do milho, também ataca o cartucho do gladíolo.

Hoje, a mais importante doença dessa cultura é a ferrugem (Uromyces transversalis (Thüm.) Wint.) que foi constatada pela primeira vez no Brasil em 1981, provavelmente introduzida por material proveniente da Argentina. Outro fungo importante é o responsável pela podridão seca (Stromatinia gladioli (Drayt.) Whetz), que aparece durante as temperaturas baixas em cultivos de inverno, permanecendo no solo por 30 ou mais anos. As viroses detectadas no País são causadas pelo Cucumber mosaic virus (CMV) e pelo Potyvirus, Bean yellow mosaic vírus (BYMV), que produz sintoma de mosaico de diferentes intensidades, deformação, quebra da coloração nas flores.

As cores atualmente oferecidas ao mercado são: branca, rosa, vermelha, salmão, amarela, verde e roxa. O consumidor brasileiro mostra nítida preferência pelas flores brancas, com cerca de $40 \%$ de participação no mercado. Estas são particularmente empregadas nas cerimônias fúnebres, na ornamentação popular de casamentos e nas oferendas a Iemanjá, nas datas comemorativas do orixá ( 2 de fevereiro, especialmente no estado da Bahia e 8 de dezembro em São Paulo e outras regiões do País) e no Réveillon. Em seguida, observa-se o gosto pelas flores vermelhas $(25 \%)$, especialmente por ocasião do Natal e, finalmente, pelas outras colorações - amarela (12\%), rosa $(10 \%)$, coral/creme $(10 \%)$ e roxa $(3 \%)$ - especialmente para consumo no Dia de Finados.

A seguir, estão relacionadas as variedades mais cultivadas e disponíveis para os produtores. Estão assinaladas com asterisco (*) as cultivares protegidas, multiplicadas no Brasil mediante o pagamento de royalties.

Vermelho: 'Red Beauty', 'Traderhorn';

Branco: 'White Friendship', 'Priscilla', 'White Goddess', 'Amsterdam';

Rosa: 'Rosa Friendship', 'Rose Supreme', 'Veronica';

Laranja: 'Peter Pears' (conhecida como "Coral");

Amarelo: 'Gold Field';

Lilás: 'Her Majesty';

Roxo: 'Purple Flora'*;

Verde: 'Green Star'*;

Bicolor: 'Nova-lux', 'Jester', 'Jester Gold', 'Baton'.
Anualmente, as áreas de plantio têm sido deslocadas como forma de prevenção ao ataque de pragas e doenças especialmente do solo. Isso tem ocorrido ao longo dos últimos trinta anos com cerca de 50 hectares plantados nos platôs da região Nordeste do Estado de São Paulo, a aproximadamente $700 \mathrm{~m}$ de altitude, com irrigação por aspersão feita por pivô central em $100 \%$ da área de plantio. O arrendamento de terras tem sofrido forte competição com a produção agrícola, especialmente com a cultura da batata.

O mercado brasileiro de gladíolos - que havia sofrido importante desaceleração ao longo das últimas décadas - voltou a crescer recentemente, a partir do lançamento de novas cultivares de cores fortes e inusitadas e, também, pela iniciativa de campanhas de promoção focadas em floristas e decoradores de todo o Brasil.

O gosto e a apreciação por essa flor haviam se desgastado junto ao consumidor brasileiro especialmente devido a dois fatores. Em primeiro lugar, por uma oferta abundante originada dos produtores de Holambra, que saturou o mercado e vulgarizou o produto por um longo período de tempo. Em segundo, por ter se tornado comum na ornamentação de cemitérios, associando fortemente sua imagem ao consumo funerário, com consequente rejeição de seu uso em cerimônias alegres e festivas.

Atualmente, contudo, pode-se observar um movimento de renovação no consumo do produto e de um novo ciclo de expansão da base produtiva.

A produção brasileira está concentrada especialmente no Estado de São Paulo, na região dos municípios de Holambra e de Santo Antonio de Posse. Em seguida, destacam-se as áreas cultivadas no Estado do Rio de Janeiro (Nova Friburgo), Pernambuco (Gravatá), Bahia e Rio Grande do Sul.

As hastes são classificadas por variedade e tamanho, amarradas com elásticos, embaladas e colocadas em pé dentro de baldes/cochos com aproximadamente $5 \mathrm{~cm}$ de água no fundo.

São confeccionados 8 feixes de 20 hastes, totalizando 160 hastes, transportados na posição vertical para evitar deformações das hastes.

O padrão de comercialização da Cooperativa Veiling Holambra estipula padrões para as hastes, cujos comprimentos e diâmetros definem suas classes: média $(75 \mathrm{~cm}$ de comprimento e diâmetro mínimo de $0,5 \mathrm{~cm})$; longa $(90 \mathrm{~cm}$ de comprimento e diâmetro mínimo de $0,8 \mathrm{~cm})$; e extra $(110 \mathrm{~cm}$ de comprimento e diâmetro mínimo de $1,0 \mathrm{~cm}$ ). As hastes de gladíolo devem apresentar um mínimo de $40 \%$ de pendão floral em relação ao seu comprimento total. Para efeito de classificação da qualidade das flores, são considerados defeitos graves (danos ocasionados por pragas e doenças) e leves (danos mecânicos, queimaduras de sol, hastes moles por deficiência nutricional e folhas amareladas).

\section{AMARÍLIS}

Estima-se que a produção anual de amarílis no Brasil seja atualmente da ordem de 17 milhões de bulbos, principalmente dirigidos ao comércio internacional, e de 500 mil vasos para comercialização no mercado interno.

Os maiores produtores são os Estados de São Paulo (Holambra) e Ceará (Paraipaba), este último totalmente focado na produção de bulbos para exportação. Neste caso, os bulbos são menores, raramente ultrapassando os $26 \mathrm{~cm}$ de diâmetro após dois ciclos de plantio em campo. 
Existem quatro empresas produtoras no Brasil, voltadas tanto ao mercado interno quanto ao externo. São elas: André Boersen, Ecoflora Plantas Ornamentais, Companhia Bulbos do Ceará (CBC) e Terra Viva Bulbos, considerada a principal produtora. De um modo geral, $60 \%$ de toda a produção destina-se ao comércio internacional e $40 \%$ se volta para a produção de vasos e flores de corte para consumo no mercado interno.

Segundo a empresa Terra Viva, o mercado brasileiro tem a seguinte preferência de consumo, segundo a coloração das flores: vermelho e vermelho/alaranjado $(70 \%)$, bicolores de rosa e branco (10\%), branco (10\%) e bicolores de vermelho e branco $(10 \%)$.

\section{Principais parâmetros da produção à comercialização}

As cultivares podem ser multiplicadas por meio de bulbilhos laterais, que produzem três ou mais bulbilhos/bulbo/ ano, ou por escamas duplas. A produção de bulbos comerciais a partir de bulbilhos leva de dois a três anos, dependendo do tamanho do bulbilho e das condições de cultivo. O método de escamas duplas é utilizado em $20-25 \%$ do volume da produção para introdução de novas cultivares, renovação do plantel e cultivares com menor capacidade de perfilhamento. A micropropagação não é empregada.

As cultivares de amarílis tiveram suas primeiras hibridações feitas no século XVIII na Europa pelo cruzamento entre espécies brasileiras e peruanas de Hippeastrum. Atualmente, as variedades mais cultivadas e comercializadas no Brasil são: Vermelha: 'Red Lion', 'Ferrari', 'Bingo', 'Red Knight', 'Orange Souvereign', 'Bolero';

Laranja: 'Desire';

Branca: 'Intokasie', 'Matterhorn';

Rosa: 'Piquant', 'Vera', 'Apple Blossom', 'Sidney', 'André'; Bicolor: 'Gilmar', 'Vision', 'Minerva', 'Estrela'; 'Angelique'.

O volume produzido de amarílis do grupo gracillis tem sido pequeno, porque não são bem aceitos no mercado interno e de exportação. $\mathrm{O}$ custo de produção é praticamente o mesmo dos amarílis comuns, porém o bulbo é menor e o preço de mercado é mais baixo, o que inviabiliza sua produção. A única variedade ainda em produção é a 'Carina'.

O Instituto Agronômico (IAC) desenvolve, desde 1982, um programa de melhoramento genético com esse gênero botânico, tendo como base a exploração da variabilidade genética das espécies nativas e seu objetivo é a criação de cultivares adaptadas às condições brasileiras. $\mathrm{O}$ intercruzamento varietal em Hippeastrum, além de conservar genótipos de espécies botânicas de difícil cultivo, tem produzido uma infinidade de híbridos de interesse agronômico e comercial.

Como fruto de uma parceria entre o IAC e a empresa André Boersen, da região de Holambra, três híbridos (IAC Neblina, IAC Jaraguá e IAC Itatiaia) (Figuras 4, 5 e 6) já foram registrados no SNPC (Serviço Nacional de Proteção de Cultivares), e, brevemente, deverá ocorrer o lançamento de novas variedades alternativas para o mercado. As variedades IAC apresentam flores menores e haste floral longa com flores de coloração alaranjada.

A produção de bulbos é feita integralmente em campo aberto. Experiências com cultivo protegido (túnel plástico) mostraram-se economicamente inviáveis.

No pré-plantio, os bulbilhos são imersos em água quente a $49^{\circ} \mathrm{C}$, por uma hora.
Existem dois sistemas de produção:

- 1 ciclo - plantio em fevereiro e colheita em maio do ano seguinte. Este sistema é válido principalmente para as variedades 'Orange Souvereign' e 'Ferrari'.

- 2 ciclos - de 8 meses no campo com plantio em agosto/ setembro e colheita em abril/maio.

O problema em integrar esses dois sistemas reside na dificuldade de programação das atividades de plantio e colheita, quando diversas variedades estão envolvidas no processo de produção, cada uma com um ciclo diferenciado.

O ciclo da cultura no Brasil é mais curto que na África do Sul por razões de clima e cultivares diferentes. O cultivo no estado do Ceará produz bulbos de menor tamanho, dificilmente passando de $26 \mathrm{~cm}$ de diâmetro após os dois ciclos de plantio em campo. Neste estado, devido às condições de temperatura e umidade relativa do ar durante o dia, a irrigação por aspersão é feita à noite. No estado de São Paulo, os amarílis também são irrigados por aspersão.

Não existem problemas fitossanitários de difícil controle. A principal doença fúngica é a queima ou mancha vermelha das folhas (Stagonospora curtsii (Berk.) Sacc.), que também atinge o bulbo. Sob condições de alta umidade, ocasionada pelo excesso de chuvas, observa-se que algumas cultivares são mais sensíveis à Erwinia. Ultimamente tem surgido um ácaro de solo, ainda não identificado, que penetra no bulbo abrindo portas para infecções fúngicas e bacterianas.

As principais viroses detectadas no país são causadas por espécies de Potyvirus, Bean yellow mosaic virus (BYMV) e Hippeastrum mosaic virus (HiMV), que causam mosaico clorótico foliar. Há, também, relato de Groundnut ringspot virus (GRSV), espécie de Tospovirus que induz manchas circulares cloróticas.

A colheita mecânica é feita com um implemento adaptado da colheita do alho. A limpeza manual consiste na retirada de detritos de solo, escamas velhas, bem como no corte drástico do sistema radicular e folhas, já que os bulbos devem ter características adequadas à classificação mecânica, ao plantio em vasos, à venda a granel ou ao armazenamento.

O amarílis no Brasil é comercializado como flor de vaso, como flor de corte, como bulbo para exportação em grandes quantidades e como bulbos avulsos diretamente para o consumidor no varejo.

Como flor de vaso, os bulbos são comercializados já floridos em potes de tamanho de 13 a $17 \mathrm{~cm}$ de diâmetro (Figura 7).

A Cooperativa Veiling Holambra tem padrões rígidos para a comercialização de amarílis em vasos no mercado, contemplando critérios de altura (entre 23 e $46 \mathrm{~cm}$ ), número de hastes por vaso (1 ou 2), diâmetro de hastes (mínimo de 1,5 $\mathrm{cm}$ ), tamanho do botão floral (de 8 a $12 \mathrm{~cm}$ ), ponto de abertura (botões fechados ou em início de abertura) e conformação geral da planta (hastes firmes e retilíneas, bulbos cobertos ou parcialmente cobertos e bem fixados no vaso). De acordo com a distribuição de tais características, os vasos são classificados em Classes I, II ou III.

Além das classes, são atribuídas também diferentes categorias aos produtos, decorrentes da avaliação de parâmetros de qualidade. São consideradas as categorias A1, A2 e B, definidas pelos percentuais máximos permitidos em cada uma quanto à ocorrência de defeitos como danos mecânicos, danos ocasionados por pragas e/ou doenças e folhas amareladas por queimaduras, deficiências nutricionais, fitotoxidez ou outros fenômenos. 
Para esse produto, os picos de venda são alcançados no Dia das Mães e no Natal, porém, é possível encontrar flores praticamente durante todo o ano.

O Hippeastrum como flor de corte é ainda considerado uma novidade no mercado brasileiro. Sua comercialização se dá somente na primavera, especialmente durante o mês de setembro. De acordo com informações do setor, em 2010, um único produtor chegou a comercializar 60 mil hastes em cores variadas para o mercado atacadista.

Apesar de sua pouca representatividade, já existem normas e parâmetros de padronização para a classificação comercial de suas flores, que estão sendo aplicados pelas principais cooperativas de produtores no mercado. Para essas flores, as hastes deverão ter no mínimo $40 \mathrm{~cm}$ de comprimento, podendo ser classificadas como finas ( $\leq 7 \mathrm{~cm}$ de diâmetro da haste), intermediárias (entre 8 e $10 \mathrm{~cm})$ ou grossas $(>10 \mathrm{~cm})$. As flores, por sua vez, são classificadas em pequenas $(<10 \mathrm{~cm}$ de diâmetro), médias $(\geq 10 \mathrm{~cm} \leq 17 \mathrm{~cm})$ ou grandes $(>17$ $\mathrm{cm})$. Para embalagem, são recomendadas caixas de papelão contendo 40 hastes, sendo 8 pacotes com 5 hastes cada um.

O Brasil é um tradicional exportador de bulbos de amarílis para Holanda (92\%), EUA (5\%) e Canadá (3\%). Para a exportação, os bulbos induzidos ao florescimento são transportados em containeres e mantidos em câmara fria a $13^{\circ} \mathrm{C}$ durante todo o transporte, realizado quase que exclusivamente por via marítima.

Outra parte é comercializada em vasos para o mercado nacional. Este mercado tem crescido cada vez mais, impulsionado pela crescente comercialização em pontos de venda ao varejo. As variedades mais vendidas apresentam têm flores de coloração vermelha, detendo $70 \%$ da preferência dos consumidores.

Para os bulbos, aplica-se a limpeza manual, operação que consiste na retirada dos detritos de solo, escamas velhas, bem como corte drástico do sistema radicular e folhas, já que os bulbos devem ter características adequadas à classificação mecânica, ao plantio em vasos, à venda a granel ou ao armazenamento.

Finalmente, a venda de bulbos avulsos é ainda bastante incipiente no Brasil. Uma das inovações atraentes observadas no mercado é a comercialização de bulbos acondicionados em pequenas cartelas, com uma, duas ou três unidades cada. Essas cartelas são expostas em "displays" com identificação do produtor (Figura 9) e podem ser encontradas pelos consumidores em supermercados, "garden centers" e lojas de conveniência em postos de combustíveis nas principais autoestradas brasileiras, entre outros pontos de venda.

\section{ALSTROEMÉRIA}

A alstroeméria é originária da América do Sul, sendo encontrada no Brasil nos mais diversos ambientes ecológicos, principalmente nos cerrados, campos de altitude e, mais raramente, nas matas tropicais. No Brasil existem cerca de 40 espécies de alstroemérias que chegam a atingir até 1,5 metro de altura. As flores são pequenas e tubulares, medindo entre 3 e $5 \mathrm{~cm}$ de comprimento por 1 a $3 \mathrm{~cm}$ de largura.

No Chile, as espécies ocorrem, sobretudo, nas áreas montanhosas, existindo atualmente 45 espécies descritas. Desse modo, formam-se dois grupos distintos: o brasileiro e o chileno.

Com o objetivo de melhoramento genético da alstroemé- ria, o Instituto Agronômico (IAC) já promoveu expedições de coleta para formação de uma coleção de espécies nativas para intercruzamentos visando à obtenção de novas cultivares bem adaptadas aos ambientes tropicais e subtropicais predominantes no País. Deste trabalho, resultou a descrição de 14 novas espécies botânicas de ocorrência no Brasil.

\section{Principais parâmetros da produção à comercialização}

As alstroemérias comercializadas atualmente são híbridos originados, sobretudo, de espécies andinas, selecionadas e melhoradas na Holanda. Essas flores vêm conquistando altas cotações no mercado, especialmente durante os meses de inverno.

A principal cor do mercado é branca, sendo 'Fuji' a cultivar mais solicitada pelos floristas. $\mathrm{O}$ mercado nacional prefere cores puras, como a rosa ('Chanel'), a amarela ('Firenze' e 'Shakira') e a vermelha ('Fuego'). Alstroemérias bicolores são muito pouco aceitas. Normalmente, as variedades e cultivares da empresa Konst Alstroeméria dominam o mercado. As mudas, de propagação in vitro, são importadas diretamente da Holanda, e o contrato estabelecido entre o produtor e a empresa prevê o pagamento de royalties por planta/ano. Este controle tem sido muito bem feito no caso das alstroemérias e praticamente não existe pirataria neste mercado.

O plantio é feito normalmente em maio/junho ou agosto, pelo fato de a temperatura do solo estar em torno de $16^{\circ} \mathrm{C}$ nesta época, o que favorece a brotação. A densidade é de 3-4 plantas $/ \mathrm{m}^{2}$ de estufa. A produtividade média é em torno de 150-200 hastes $/ \mathrm{m}^{2} /$ ano, podendo atingir 400 hastes $/ \mathrm{m}^{2} /$ ano, dependendo da variedade e das condições de cultivo. Os canteiros permanecem em produção por 3 a 4 anos também de acordo da variedade.

As espécies de alstroemérias brasileiras têm um comportamento diverso dos híbridos cultivados. Aparentemente, a temperatura do solo também exerce influência sobre o florescimento, porém a um nível de temperatura mais elevado. Muitas espécies selvagens florescem espontaneamente no verão, o que não é comum para os híbridos holandeses, que normalmente florescem na primavera (setembro a novembro), porém, em cultivo comercial, é possível estimular o florescimento durante todo o ano, evitando-se que, no verão, permaneçam em estado vegetativo. Existem também espécies nativas que florescem no inverno, característica muito válida para a produção comercial. Um bom exemplo é a espécie $A$. caryophyllaea e seus híbridos.

As principais pragas são o pulgão, o tripes e a mosca branca (espécie ainda não identificada), e as principais doenças são a ferrugem (Uromyces alstroemeriae (Diet.) P. Henn.) e o mofo-pardo (Botrytis sp.).

Muitas viroses já foram identificadas nessa cultura. O Cucumber mosaic virus (CMV) produz sintomas do tipo mosaico reticulado ou deformação foliar, principalmente nas folhas jovens, e manchas cloróticas. Quando associado ao Tobacco streak virus (TSV), pode induzir manchas cloróticas e necróticas em quase toda a superfície foliar. O Tomato spotted wilt tospovirus (TSWV) produz sintomas que podem variar de anéis cloróticos a desenhos necróticos. Também foram detectadas espécies de Potyvirus induzindo riscas cloróticas e mosaico e de Carlavirus, que causa faixas cloróticas nas folhas. É frequente a infecção mista, isto é, a ocorrência de mais de uma espécie de vírus em uma mesma planta. 


\section{Colheita, pós-colheita e comercialização}

A colheita é realizada quando os botões começam a se abrir e a se colorir. O ramo é arrancado, dependendo da variedade, altura do cultivo e estrutura do solo.

As alstroemérias são acondicionadas em ramalhetes de 10 a 12 hastes de 60 a $70 \mathrm{~cm}$ de altura, que é o padrão do mercado. Podem variar desde 40 a até $90 \mathrm{~cm}$. A padronização é feita normalmente com uma única cor por caixa, que contém de 10 a 12 maços. Para pequenas floriculturas, as caixas são feitas em maços de diferentes cores. Para maior proteção das flores, esses ramalhetes são acondicionados em caixas de papelão (Figura 8).

A comercialização de alstroemérias é crescente no mercado brasileiro, tendo mais que dobrado suas quantidades ofertadas nos principais mercados atacadistas entre os anos de 2008 e 2010. A disponibilidade das flores é mais intensa a partir do final do mês de julho, estendendo-se até dezembro.

A produção está atualmente concentrada em mais de $90 \%$ no Estado de São Paulo. A segunda região em importância de cultivo é o Estado de Minas Gerais, com pouco mais de $8 \%$ do mercado. Pequenas contribuições são observadas, ainda, por alguns municípios dos Estados do Rio Grande do Sul, Paraná e região serrana do Rio de Janeiro.

No Estado de São Paulo, os principais municípios produtores são: Holambra, Atibaia, Ibiúna, Jacareí, Nazaré Paulista, Pouso Alegre e Cotia.

\section{COPO-DE-LEITE}

Trata-se de planta de introdução muito antiga no País, cujo registro se perde no tempo. No Estado de Minas Gerais, os platôs da região Centro-Sul apresentam características climáticas favoráveis para o cultivo desta espécie que coloniza espontaneamente as áreas úmidas das baixadas e beiras de córregos.

O cultivo de copo-de-leite é feito quase que exclusivamente por pequenos floricultores, não despertando o interesse das médias e grandes empresas do setor, a não ser como produto de exploração alternativa. $\mathrm{O}$ cultivo protegido não chega a compensar financeiramente e já foi detectada a ocorrência do vírus Dasheen mosaic virus (DsMV) do gênero Potyvirus, o qual causa manchas cloróticas, anéis necróticos e amarelecimento das folhas. O copo-de-leite verde é produzido, principalmente, no Estado de São Paulo, em telado ou túnel plástico para a obtenção de hastes mais longas, mas o período de produção é muito curto, principalmente maio/junho, chegando até outubro.

O copo-de-leite floresce em abundância nos meses mais frios, entre maio e setembro. No verão, ocorre alta incidência da bactéria Erwinia carotovora. Este patógeno se tornou de maior importância desde a introdução dos novos híbridos coloridos de copo-de-leite, obtidos por hibridações entre as espécies $Z$. rehmanii e Z. elliotianna, adaptadas às zonas mais frias e secas dos platôs da África.

As variedades coloridas são de introdução recente no Brasil e sua chegada causou grande impacto no mercado. Sua produção, porém, permanece bastante incipiente, pois o principal problema é seu custo. As condições climáticas pouco favoráveis obrigam o cultivo protegido com controle de água e temperatura, onerando sobremaneira o custo de produção, não garantindo resultado econômico-financeiro atraente para a atividade.

Atualmente, $95 \%$ das variedades mais cultivadas para vaso são as coloridas, e as brancas correspondem a apenas 5\%:
Branco: 'Captain Ventura';

Amarelo: 'Captain Sonora', 'Captain Aquila', 'Captain Serrada', ' Florex Gold';

Vermelho: 'Captain Murano';

Laranja: 'Captain Safari';

Rosa: 'Captain Romance';

Vinho: 'Captain Reno';

Negro: 'Schwarzwalder'.

Para a produção de flores de corte, a preferência do mercado é $40 \%$ amarelo, $25 \%$ laranja, $25 \%$ rosa e $10 \%$ outras cores.

As principais regiões de produção estão concentradas nos Estados de São Paulo, especialmente nos municípios de Guarulhos, Arujá, Cotia e Ibiúna, Minas Gerais e região serrana do Espírito Santo. A oferta no mercado atacadista mostra nítida redução durante o verão, nos meses de janeiro a março.

\section{Principais parâmetros da produção à comercialização}

Os bulbos de tamanho 16, 18 e 20 são importados de Holanda aptos a florir. O reaproveitamento dos bulbos para uma segunda florada é muito pequeno.

$\mathrm{O}$ cultivo é feito em áreas bem drenadas, porém com irrigação constante de forma a manter a umidade elevada. $\mathrm{O}$ copo-de-leite desenvolve-se melhor quando cultivado em regiões com temperatura média entre 16 e $22^{\circ} \mathrm{C}$, no entanto, suporta até $4^{\circ} \mathrm{C}$. Na região de Holambra-SP, a produção em vaso emprega o sistema "pad-fan".

A média de colheita por bulbo está entre 5 e 8 flores, em função da variedade, do local e da qualidade do bulbo.

Emprega-se o tratamento pós-colheita das hastes por imersão para prevenção de Erwinia carotovora com solução de cloro (1ppm).

O mercado brasileiro de copo-de-leite pode ser considerado levemente decadente, com volumes ligeiramente decrescentes de produção e comercialização nos últimos anos. Os copos-de-leite brancos são particularmente apreciados em ornamentações de casamentos. Já os verdes ou coloridos são utilizados em decorações de cerimônias ou ambientes mais sofisticados. O mercado atacadista mostra nítida redução de oferta durante o verão, de janeiro a março.

No caso dos copos-de-leite brancos, os principais motivos para a diminuição do consumo são a baixa durabilidade póscolheita das flores e a alta susceptibilidade a danos mecânicos no transporte e manuseio das flores. Já para as calas coloridas, as restrições dizem respeito mais aos altos preços das flores e à oferta irregular no mercado.

A comercialização pode ser feita para hastes cortadas, em vasos (potes de 13 a $17 \mathrm{~cm}$ ) e em bulbos em redes plásticas e/ou cartelas (Figura 9). No mercado, os copos-de-leite são classificados de acordo com o tamanho das hastes: curta (40 $\mathrm{cm})$, média $(60 \mathrm{~cm})$ ou longa $(80 \mathrm{~cm})$. Após a classificação, as hastes são acondicionadas em maços de dez unidades, envolvidas em plástico, que serve de proteção, e armazenadas em câmaras frias. Para comercialização, são embaladas em caixas de papelão, com tamanhos específicos para cada comprimento de haste. Cada caixa de papelão comporta 80 flores.

\section{HEMEROCALE}

Roberto Burle Marx, célebre paisagista brasileiro mundialmente respeitado, valorizou muito os novos híbridos americanos de hemerocale em seus projetos. Até então no País existiam apenas as antigas formas de Hemerocallis fulva, $H$. 
flava e H. lilioasphodelus. Nos seus revolucionários projetos paisagísticos, o paisagista gostava de utilizar essas plantas em manchas puras, com apenas uma cor ou misturando diversas cultivares. Outras possibilidades exploradas eram também as mesclas com outras espécies ornamentais, tais como Setcreasea purpurea, Clorophytum comosum 'Variegatum', Eragrostis curvula e Crinum americanum, formando arranjos e desenhos geométricos ou de formato orgânico.

As variedades americanas então introduzidas no Brasil como 'Alegreto', 'Buffy's Doll', 'By Myself', 'Berlie Ferris', 'Cora Ofter', 'Little Fellow', 'Loonie', 'Red Waves', 'Shadyside', 'Sirococo', 'Stella D'oro' e 'Summerwine' serviram de base para um programa de melhoramento genético desenvolvido durante muitos anos em colaboração com o Instituto Agronômico (IAC) e a empresa Agrícola da Ilha Ltda., do Estado de Santa Catarina. Este trabalho foi desenvolvido durante 12 anos e contou também com a colaboração do melhorista alemão Ernest Stoberg.

Desde então, dezenas de novas cultivares foram selecionadas e são comercializadas em todo o mercado nacional (Figura 10). As principais são: 'Alessandra', 'Atelene Normann Kämpf', 'Amanda', 'Anita', 'Bárbara', 'Canário', 'Carolina', 'Campinas', 'Cassiane Pereira Velho', 'Cora Coralina', 'Corupá', 'Dona Francisca', 'Dona Toni’, 'Dorinha', 'Graziela Barroso', 'Gabriel Matheus Nass', 'Joinville', 'Jundiaí', 'Ligia Fagundes Telles' 'Maria Bonita', 'Olga Ullmann', 'Rainha Sílvia', 'Regina M. Rodrigues', 'Santa Catarina', 'São Paulo' e 'Santa Elisa'. Atualmente no catálogo de 2010, são oferecidas 53 diferentes cultivares e um total de mais de um milhão e trezentas mil mudas produzidas anualmente.

\section{Principais parâmetros da produção à comercialização}

As pragas que atacam o hemerocale são: os afídeos (Myzus persicae), que acarretam a presença do fungo fumagina, os tripes (Frankliniella tritici e F. hemerocallis), ácaros, formigas cortadeiras e os nematoides (Meloidogyne spp.).

A introdução de novas cultivares americanas acarretou a entrada do fungo Puccinia hemerocallidis causador da ferrugem, que se tornou a doença mais séria do hemerocale no país. Este fungo de cor alaranjada ataca a folhagem principalmente nos meses mais secos do ano e no inverno.

No Brasil, o único relato de vírus encontrado é o Tomato mosaic virus (ToMV), espécie pertencente ao gênero Tobamovirus, cujos sintomas são manchas cloróticas e necróticas.

A produção comercial e o consumo em projetos paisagísticos concentram-se nas regiões Sul e Sudeste do Brasil, pois as condições climáticas mais quentes do restante do País não permitem o florescimento do hemerocale. A melhor época para o plantio é o mês de outubro ou no final da florada. Cada haste pode florescer pelo período de 3 a 6 semanas e produzir até 50 botões florais.

A Agrícola da Ilha organiza anualmente, desde 2003, o Festival Brasileiro de Hemerocallis, na cidade de Joinville, Estado de Santa Catarina (Figuras 11 e 12). O evento abrange 14 hectares de área ao ar livre, recebendo mais de 10 mil visitantes, entre profissionais do ramo e consumidores finais. O festival é realizado sempre no mês de novembro, época em que a cidade atrai milhares de visitantes para a Festa das Flores, que acontece desde 1936.

\section{OUTRAS BULBOSAS ORNAMENTAIS}

Existem algumas empresas no Brasil que comercializam diretamente no mercado de varejo em pequena escala. Entre as principais encontram-se: André Boersen, Premium Seeds e Roselândia. Os bulbos são parcialmente produzidos nas propriedades dessas empresas e parcialmente importados ou produzidos por pequenos agricultores terceirizados.

Os bulbos são comercializados via Internet, através de homepages próprias das empresas citadas, e as entregas feitas via correios. Também podem ser adquiridas em garden centers, lojas de sementes e produtos para horticultura, supermercados e lojas de conveniência em postos localizados nas principais rodovias. Para esse atendimento, os bulbos são embalados em pequenas quantidades, ou individualmente, em redes plásticas e cartelas, devidamente etiquetadas e expostas em displays próprios.

Atualmente, as principais espécies comercializadas são: Acidanthera bicolor, Tulbaghia violácea, Polianthes tuberosa, Canna indica, Crinum sp., Dahlia sp., Freesia sp., Gloriosa rothschilriana, Iris sp., Ixia flexuosa, Hyacinthus orientalis, Hymenocallis sp., Amaryllis belladonna, Zephyranthes sp., Scadoxus multiflorus, Narcissus sp., Ornithogalum sp., Caladium X hortulanum, Tulipa hybrida.

\section{AGRADECIMENTOS}

Os autores agradecem a colaboração de:

- Srs. André e Peter Boersen, produtores em Holambra-SP e Andradas, MG;

- Sr. Luiz Octávio Cavicchio, gerente comercial da Fazenda Terra Viva, Holambra-SP;

- Sra. Ana Paula Sá van der Geest, Flortec - Treinamentos, Cursos e Eventos Ltda.;

- Sr. Dário Bergemann, Agrícola da Ilha Ltda.;

- Sr. Jan Zuijderwijk, Asista Consultancy;

- Sra. Ana Rita Pires Stênico, Gerente do Mercado Permanente de Flores da Ceasa Campinas;

- Sr. Carlos Godoy, Gerente da Divisão Comercial da Cooperativa Veiling Holambra; e

- Sr. Flávio Godas, Chefe do Departamento de Economia e Estatística da Ceagesp.

\section{BIBLIOGRAFIA}

ABCSEM - Associação Brasileira do Comércio de Sementes e Mudas. Quatro décadas - a trajetória da ABCSEM. Campinas, 2010, $99 \mathrm{p}$.

AGRÍCOLA DA ILHA. Hemerocallis: Catálogo. Joinville: Agrícola da Ilha, s/d.

ALEXANDRE, M.A.V.; DUARTE, L.M.L.; CAMPOS-FARINHA, A.E.C. Plantas ornamentais: doenças e pragas. São Paulo: Instituto Biológico, v. 1, 2008, 319 p.

ALEXANDRE, M.A.V.; RIVAS, E.B.; TOZETTO, A.R.P.; DUARTE, L.M.L. Lista comentada sobre a ocorrência natural de vírus em plantas ornamentais no Brasil. São Paulo: Instituto Biológico, 2005, 55 p.

ALMEIDA, E.F.A.; PAIVA, P.D.O. Cultivo de copo-de-leite. Informe Agropecuário, Belo Horizonte, v. 25, n. 227, p. 30$35,2005$.

COOPERATIVA VEILING HOLAMBRA. Departamento de Qualidade e Pós-colheita. Critérios de Classificação para 
Alstroeméria de corte. Holambra, São Paulo, 2010.

COOPERATIVA VEILING HOLAMBRA. Departamento de Qualidade e Pós-colheita. Critérios de Classificação para Amaryllis em Vaso. Holambra, São Paulo, 2010.

COOPERATIVA VEILING HOLAMBRA. Departamento de Qualidade e Pós-colheita. Critérios de Classificação para Gladíolo de Corte. Holambra, São Paulo, 2010.

COOPERATIVA VEILING HOLAMBRA. Departamento de Qualidade e Pós-colheita. Critérios de Classificação para Lírio de Corte. Holambra, São Paulo, 2010.

COOPERATIVA VEILING HOLAMBRA. Departamento de Qualidade e Pós-colheita. Critérios de Classificação para Lírio de Vaso. Holambra, São Paulo, 2010.

COUTINHO, L.N.; RUSSOMANNO, O M.; FIGUEIREDO, M.B. Uromyces alstroemeriae uma severa e importante ferrugem da Alstroemeria spp. cultivada. O Biológico, São Paulo, v.61, n.1, p 23-26, 1999.

DUARTE, L.M.L., SEABRA, P.V., RIVAS, E.B., GALLETI, S.R., ALEXANDRE, M.A V. Single and double viral infection in Alstroemeria sp. Revista Brasileira de Horticultura Ornamental, Campinas, v.5, n.1, p. 24-33, 1999.

FAUQUET C.M., MAYO M.A., MANILOFF J., DESSELBERGER U., BALL L.A. Virus Taxonomy. Eighth report of the International Committee on Taxonomy of Viruses. Elsevier/ Academic Press, San Diego, CA, USA. 2005, 1259 p.

JUNQUEIRA, A.H.; PEETZ, M.S. Desempenho recente e tendências da floricultura brasileira. Agrianual 2011, AgraFNP, SP, p.291-294, 2010.

JUNQUEIRA, A.H.; PEETZ, M.S. El Día de La Madre 2010 en Brasil. Plantflor, Almería, Espanha, Verdiland Ediciones S.L. n. 139, p.2-4, 2010.

JUNQUEIRA, A.H.; PEETZ, M.S. Floricultura brasileira em 2010: um balanço do comércio exterior e do mercado interno. Cultivar Hortaliças e Frutas, Pelotas, RS, n. 65, p. 38, fev./ mar. 2011.

JUNQUEIRA, A.H.; PEETZ, M.S. Mercado interno para os produtos da floricultura brasileira: características, tendências e importância socioeconômica recente. Revista Brasileira de Horticultura Ornamental, v.14, n.1, 2008.
LAGARES, L.M. SC - Desenvolvimento e proteção de novas cultivares de Hemerocallis. In: DUARTE, Renata Barbosa de Araújo. Histórias de Sucesso: agronegócios - floricultura, p. 67-91. Brasília: SEBRAE, 2007.

LOPES, T.O.P. Efeito da vibração na qualidade de lírios orientais de vaso. Dissertação (Mestrado). Universidade Estadual de Campinas, Faculdade de Engenharia Agrícola, 2008, 64 p.

MUÑOZ-SCHICK, M. Three new monocots discovered in Chile: Alstroemeria mollensis M. Muñoz et a. brinck (Alstroemeriaceae), Miersia chilensis var. bicolor M. Muñoz (Gilliesiaceae) and Calydorea chilensis M. Muñoz (Iridaceae). Gayana Botánica, Concepción, Chile, v. 60, n. 2, p. 101-106, 2003.

PELLEGRINI, M. B. Q. Caracterização e seleção de amarílis melhorados pelo Instituto Agronômico de Campinas - IAC para flor de corte. Dissertação (Mestrado). Curso de Pós-Graduação em Agricultura Tropical e Subtropical. IAC, Campinas, 2007.

PITTA, G.P.B.; CARDOSO, R.M.G., CARDOSO, E.J.B.N. Doenças das plantas ornamentais. São Paulo: Instituto Brasileiro do Livro Científico, 1990. 180p.

PITTA, G.P.B.; FIGUEIREDO, M.B.; CARDOSO, R.M.G.; HENNEN, J.F.; Ferrugem (Uromyces transversalis Tuemen, Winter): uma nova doença do gladíolo (Gladiolus spp.) no Brasil. O Biológico, São Paulo, v.47, n.12, p.323-328, 1981.

RIVAS, E.B. Lily Symptomless Virus no Brasil. Instituto Biológico, São Paulo. p.1-5, 2010 (Documento Técnico n. 6).

TERRA VIVA BULBOS. Amaryllis: Informativo Técnico de Produção. Holambra, SP: Terra Viva Bulbos, s/d.

TERRA VIVA BULBOS. Gladíolo: Informativo Técnico de Produção. Holambra, SP: Terra Viva Bulbos, s/d.

TOMBOLATO, A.F.C. Cultivo comercial de plantas ornamentais. Campinas: Instituto Agronômico, 2004, 211 p.

TSUBOI, N.; TSURUSHIMA, H. Introdução à história da indústria de flores e plantas ornamentais no Brasil. Arujá: AFLORD - Associação dos Floricultores da Região da Via Dutra. 2009, 266 p.

ZANELLA, M. Cadeia de produção de Zantedeschia spp. no Estado de São Paulo. Relatório de Estágio de Conclusão de Curso de Agronomia. Universidade Federal de Santa Catarina, Centro de Ciências Agrárias. Florianópolis, SC, 2006. 
Tabela 1. Dados de comercialização de flores de corte das principais espécies de bulbosas para o período 2008-2010 Table 1. Brazil - main wholesale markets

BRASIL - PRINCIPAIS MERCADOS ATACADISTAS.

Quantidades comercializadas das principais bulbosas ornamentais cultivadas para a produção de flores de corte, 2008 a 2010

\begin{tabular}{|c|c|c|c|c|c|c|c|c|c|c|c|c|}
\hline \multirow{2}{*}{ mês } & \multicolumn{3}{|c|}{ Alstroeméria (pacote) } & \multicolumn{3}{|c|}{ Copo-de-leite (dúzia) } & \multicolumn{3}{|c|}{ Gladíolo (pacote) } & \multicolumn{3}{|c|}{ Lírio (pacote) } \\
\hline & 2008 & 2009 & 2010 & 2008 & 2009 & 2010 & 2008 & 2009 & 2010 & 2008 & 2009 & 2010 \\
\hline janeiro & 58.919 & 101.003 & 106.478 & 5.913 & 6.540 & 4.090 & 30.006 & 28.517 & 24.220 & 19.310 & 15.957 & 22.883 \\
\hline fevereiro & 46.751 & 71.266 & 92.260 & 4.747 & 4.606 & 2.179 & 30.053 & 23.001 & 28.230 & 17.405 & 15.630 & 13.552 \\
\hline março & 60.253 & 88.968 & 114.724 & 7.892 & 3.246 & 2.726 & 30.721 & 20.812 & 34.615 & 24.248 & 20.802 & 17.310 \\
\hline abril & 51.978 & 60.342 & 99.585 & 8.876 & 4.962 & 5.052 & 27.880 & 22.946 & 31.417 & 23.855 & 18.380 & 16.803 \\
\hline maio & 55.752 & 60.680 & 111.990 & 13.501 & 6.837 & 8.351 & 28.925 & 22.277 & 41.785 & 22.478 & 17.819 & 19.714 \\
\hline junho & 58.648 & 72.441 & 121.223 & 17.547 & 10.000 & 9.547 & 28.401 & 22.729 & 34.685 & 22.407 & 17.789 & 20.581 \\
\hline julho & 71.720 & 103.253 & 142.006 & 21.990 & 20.233 & 21.233 & 23.307 & 19.169 & 32.856 & 18.834 & 17.469 & 19.071 \\
\hline agosto & 83.122 & 113.292 & 185.561 & 29.004 & 29.673 & 28.694 & 25.182 & 20.941 & 42.965 & 19.371 & 18.754 & 22.475 \\
\hline setembro & 104.491 & 134.210 & 212.150 & 34.169 & 36.558 & 36.883 & 23.902 & 24.540 & 33.783 & 24.009 & 25.560 & 24.011 \\
\hline outubro & 109.467 & 145.102 & 230.585 & 38.809 & 37.197 & 38.661 & 38.304 & 36.470 & 49.407 & 29.919 & 29.555 & 27.646 \\
\hline novembro & 105.010 & 147.453 & 219.877 & 21.875 & 24.644 & 31.073 & 26.599 & 25.168 & 38.292 & 27.459 & 27.226 & 29.757 \\
\hline dezembro & 110.461 & 130.382 & 236.857 & 13.890 & 10.073 & 17.183 & 30.495 & 25.085 & 40.556 & 24.167 & 20.811 & 28.859 \\
\hline Total & 916.571 & 1.228 .394 & 1.873.297 & 218.215 & 194.571 & 205.672 & 343.774 & 291.653 & 432.811 & 273.462 & 245.752 & 262.661 \\
\hline
\end{tabular}



Figura 1. "Veiling", Leilão de flores em Holambra. Vista dos carrinhos.

Figure 1. "Veiling", the Holambra's flower auction. View of the chariots.

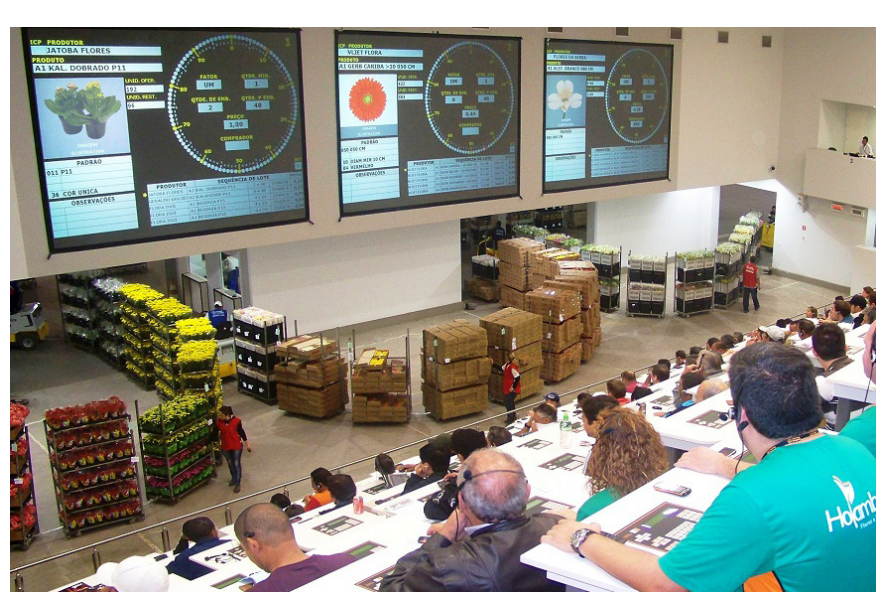

Figura 2. "Veiling", Leilão de flores em Holambra. Vista do relógio.

Figure 2. "Veiling", the Holambra's flower auction. View of the sale clocks.

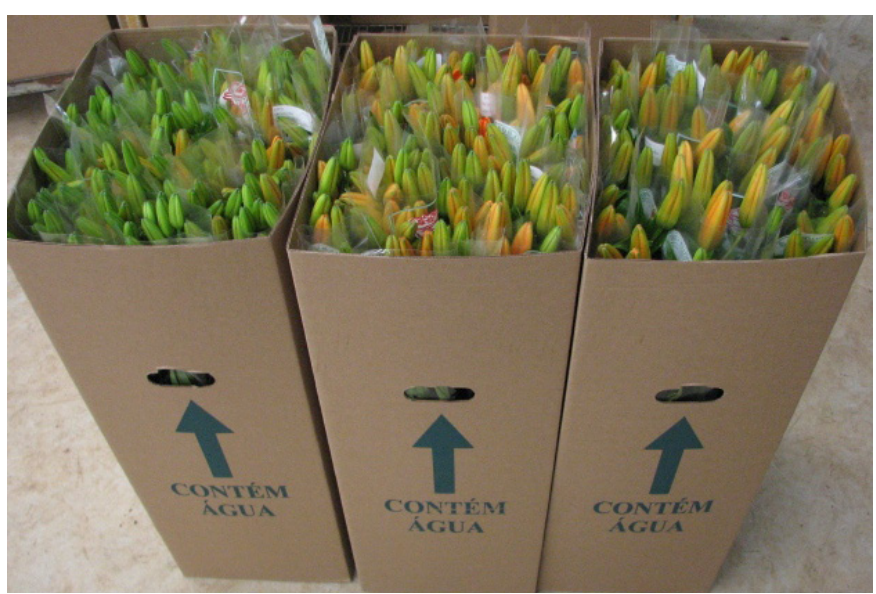

Figura 3. Caixa de papelão contendo hastes de lírio prontas para o Mercado atacadista.

Figure 3. Paper box containing lily stalks ready for wholesale market. 


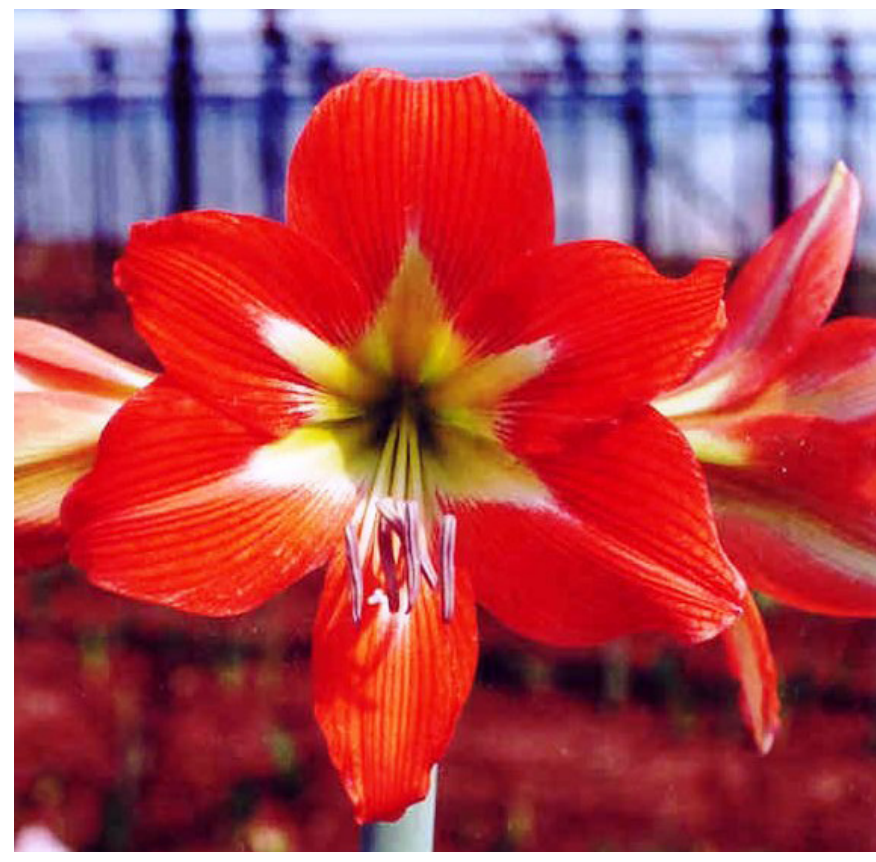

Figura 4. Amarílis 'IAC Neblina' (IAC 207).

Figure 4. Amaryllis 'IAC Neblina'(IAC 207).

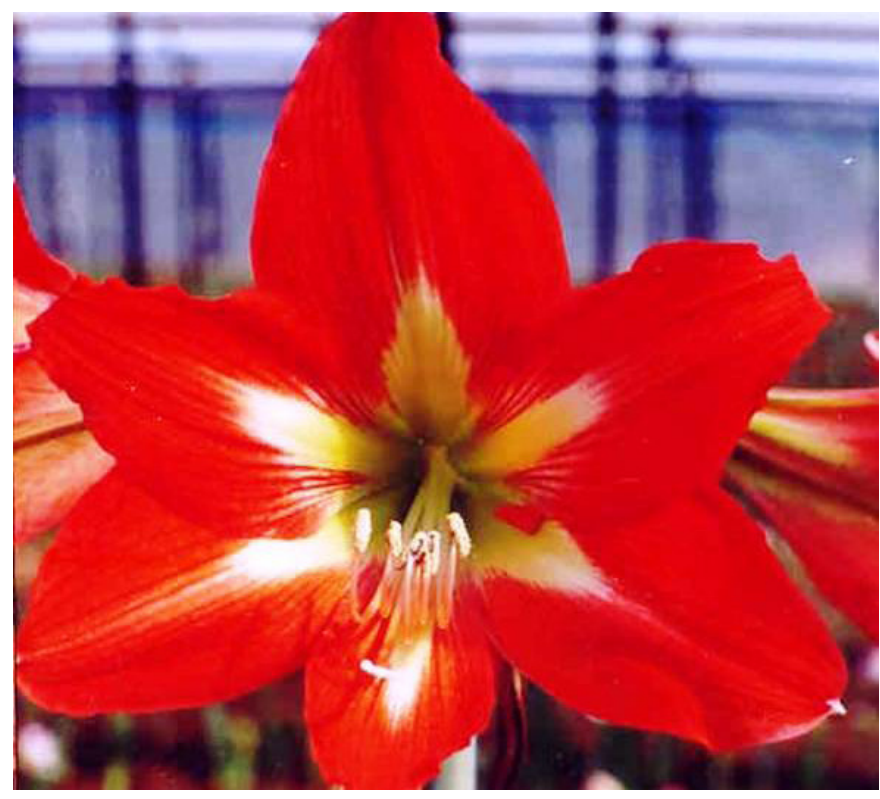

Figura 6. Amarílis 'IAC Itatiaia' (IAC 208).

Figure 6. Amaryllis 'IAC Itatiaia'(IAC 208).

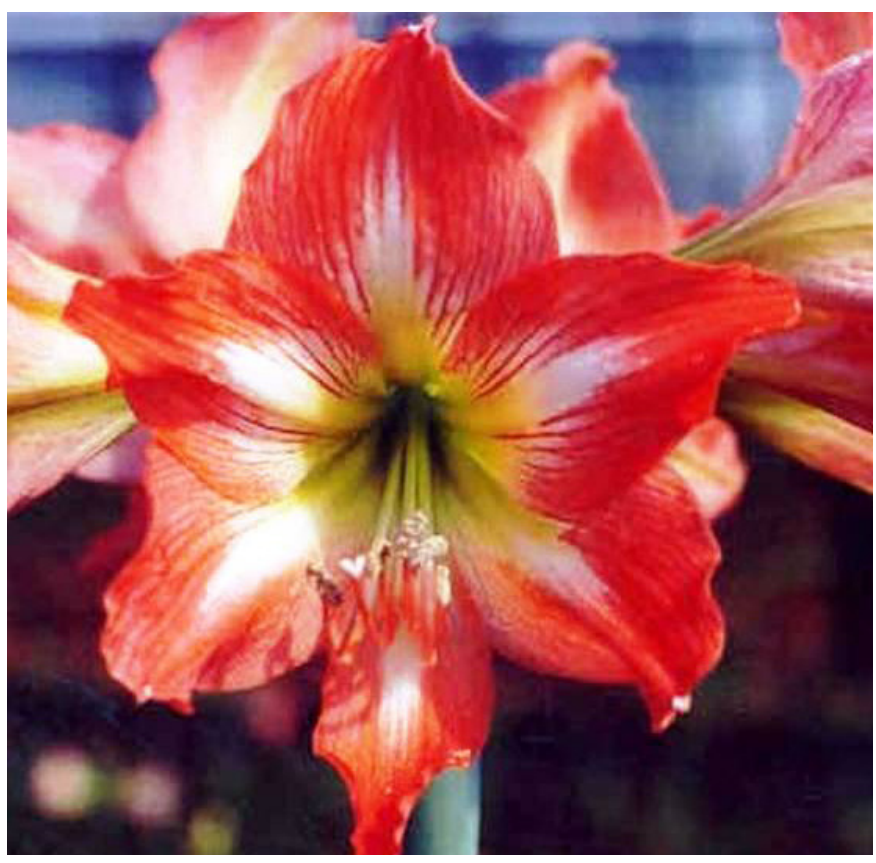

Figura 5. Amarílis 'IAC Jaraguá' (IAC 224).

Figure 5. Amaryllis 'IAC Jaraguá'(IAC 224).

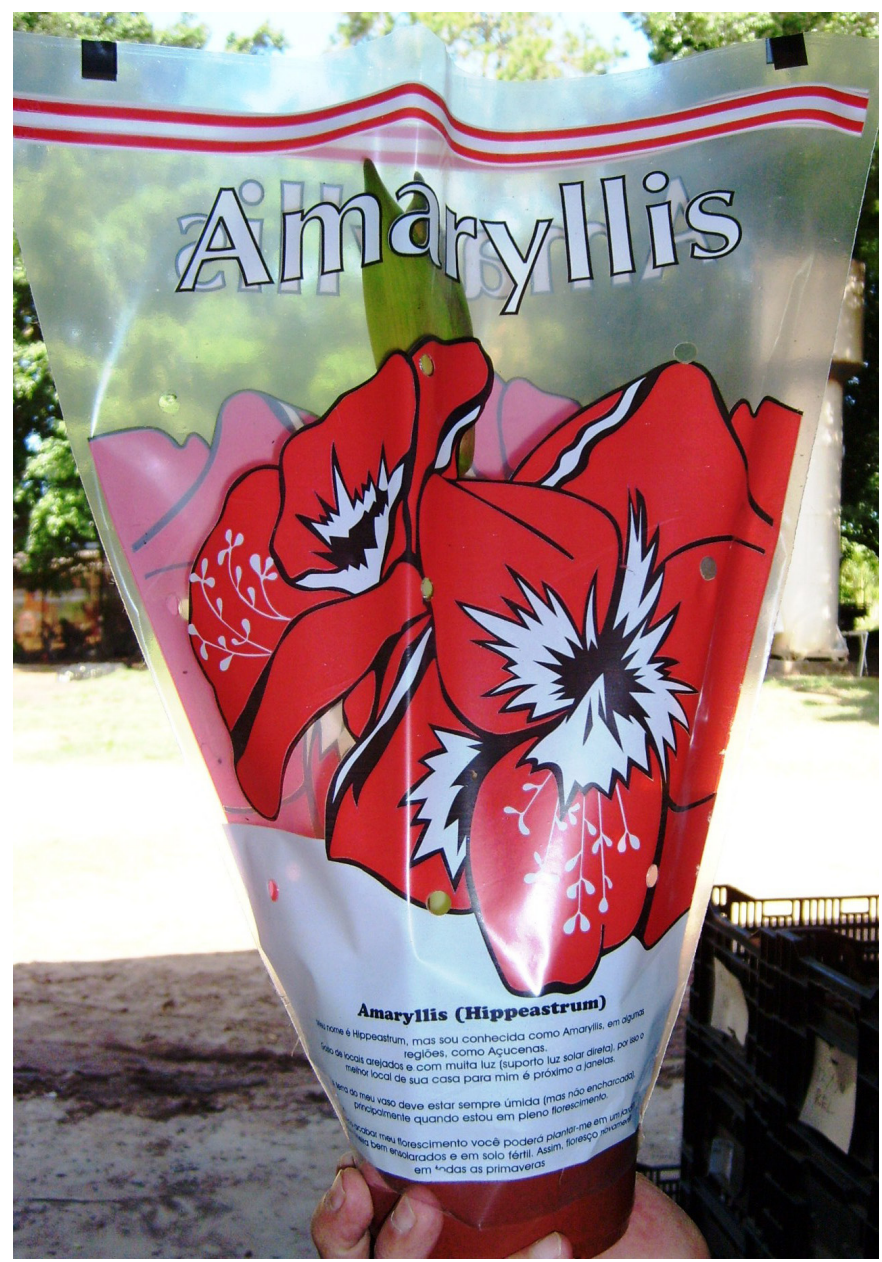

Figura 7. Vaso de amarílis embalado para o varejo. Figure 7. Amaryllis pot packing. 


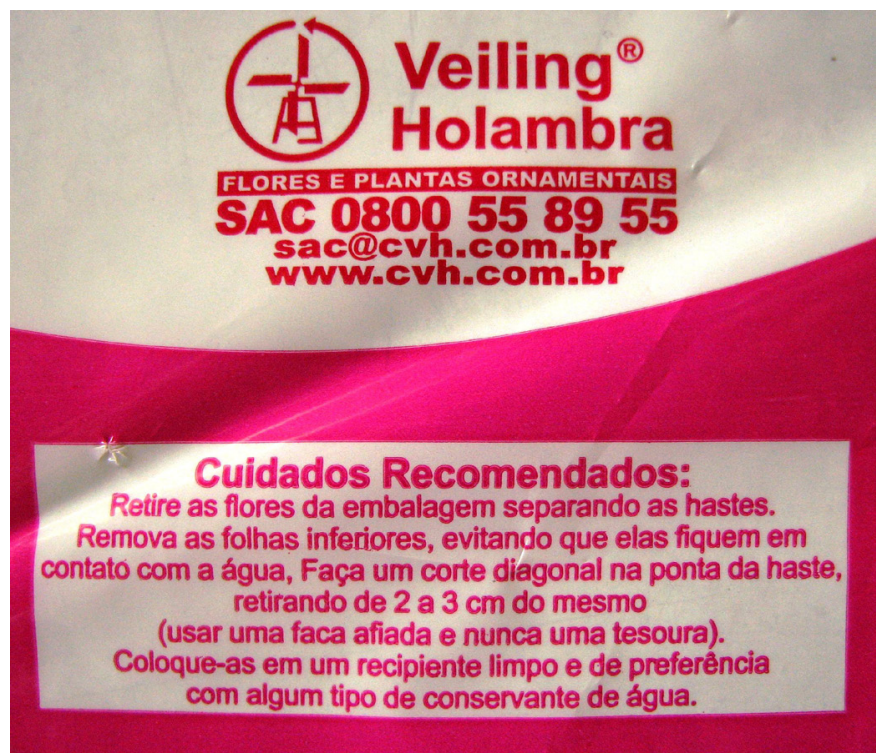

Figura 8. A etiqueta do bouquet de alstroeméria fornece instruções para o consumidor para manter a longevidade das flores.

Figure 8. The alstroemeria bouquet label gives instructions to the customer how to keep the flower vase life.

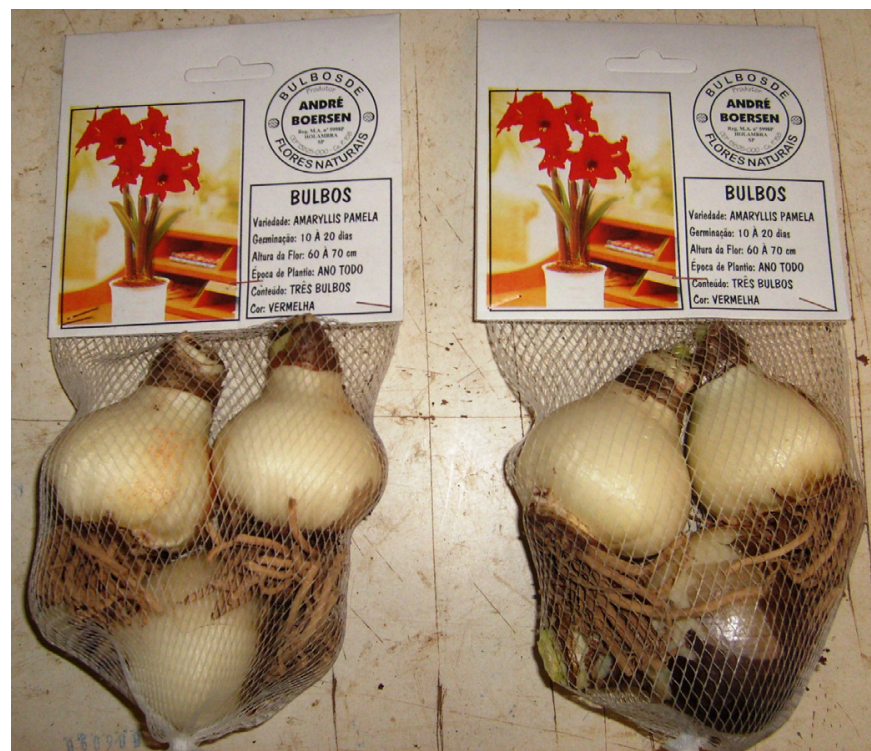

Figura 9. Embalagem desenvolvida para o comércio varejista de bulbos. Conjunto de cartela e rede plástica.

Figure 9. Plastic nets package for retail market.

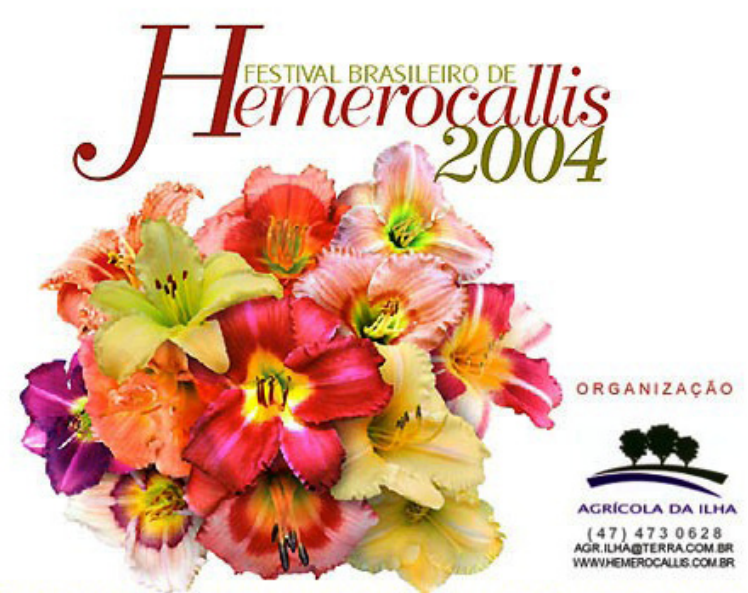

PAISAGISMO, CULTIVO E LANCAMENTOS NA CIDADE DAS FLORES

Figura 11. Folheto de propaganda do Festival do Hemerocallis de 2004

Figure 11. 2004 Daylily Festival folder.

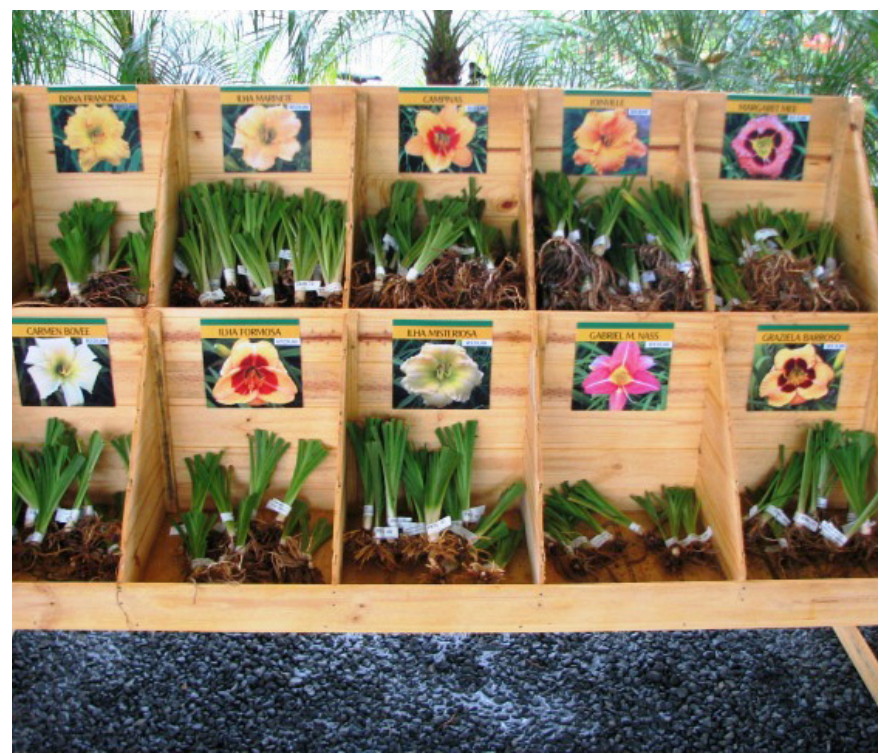

Figura 10. "Display”para venda de mudas de hemerocale, Agrícola da Ilha Ltda.

Figure 10. Display for daylily plants sale at Agricola da Ilha.

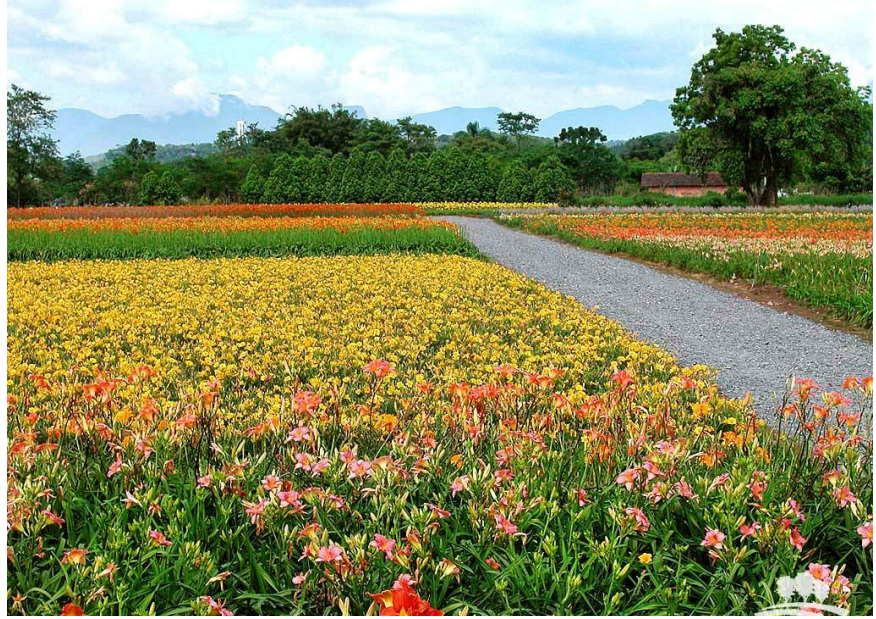

Figura 12. Campo de multiplicação de hemerocale na Agrícola da Ilha Ltda., Joinville/SC.

Figure 12. Daylily field at Agricola da Ilha Ltda., Joinville, S. Catarina State, Brazil. 